\title{
NorDiNa: På utflykt i världen!
}

\section{Välkommen till NorDiNa nr 3 (2) eller som vi i redaktionen fortsätter att tänka nr 7 !}

Den 21 till 25 augusti i år gick ESERA-konferensen av stapeln i Malmö. Samtliga NorDiNas redaktörer var på plats och den svenska delen ingick dessutom i den lokala kommittén. Konferensen arrangerades av Malmö Högskola och medarrangörer var Danmarks Pædagogiske Universitetsskole, Göteborgs Universitet samt Högskolan i Kristianstad.

Till konferensen registrerade sig hela 612 personer fördelade på 43 olika länder. ESERA är till namnet en europeisk konferens men i verkligheten en världskonferens. Av de 43 olika länderna är inte mer än drygt hälften att kategorisera till Europa geografiskt sett. Hela $25 \%$ av deltagarna på konferensen kom från utomeuropeiska länder, så varför inte säga att ESERA är en världskonferens. Alla deltagare fick i samband med registreringen ett exemplar av vår nordiska tidskrift NorDiNa. Vi tyckte att detta var ett ypperligt tillfälle att göra reklam för vår tidskrift. Därför finns nu NorDiNa på utflykt runt om i världen, åtminstone i 43 olika länder.

NorDiNa bidrog på åtminstone ytterligare ett sätt till konferensens tillblivelse. Vid reviewprocessen fanns stort behov av refereepersoner. Vi i redaktionen kunde bidra med NorDiNas refereeförteckning, som fick komplettera den som ESERA hade sedan tidigare konferenser. Detta medförde att många av er, våra referees, fanns med och bedömde de bidrag som skickades in till konferensen. Många av er var dessutom med bland författarna till de inskickade bidragen, som bestod av 121 posters, 371 papers och 38 symposier. Dessa bidrag skulle vart och ett bedömas av två oberoende referees och i och med att symposierna bestod av i genomsnitt fyra bidrag innebar det att vi allt som allt hade drygt 1200 bidrag att skicka ut. Vi hade tillgång till drygt 100 referees som bedömde ungefär 10 bidrag var. Ett gigantiskt arbete som genomfördes fantastiskt smidigt av alla våra refereepersoner. Därefter avslutades reviewprocessen av den lokala kommittén. När allt var klart hade vi 82 posters, 251 papers och 29 symposier som vi förgyllde konferensdagarna med.

$\mathrm{Nu}$ tycker vi att det passar extra bra att ta tillfället i akt och tacka er, våra NorDiNa referees, för ert ovärderliga arbete. I vår refereeförteckning finns i dagsläget hela 82 namn. I NorDiNa nr 2 november 2005 uppmärksammade vi de 52 personer fram till dess varit referees. Nu är det dags att tacka ytterligare 64 personer och som ni förstår av de antal vi här redovisar har flera av er varit referee mer än en gång. Tack till: 


$\begin{array}{ll}\text { Anat Yarden } & \text { Elisabeth Öhrn } \\ \text { Anders Berg } & \text { Ellen Henriksen } \\ \text { Andreas Redfors } & \text { Else-Marie Staberg } \\ \text { Andreas Quale } & \text { Erik Knain } \\ \text { Ann Zetterqvist } & \text { Ference Marton } \\ \text { Anna Vikström } & \text { Florentina Lustig } \\ \text { Are Turmo } & \text { Frank Bach } \\ \text { Björn Andersson } & \text { Gustav Helldén } \\ \text { Bjørn Håland } & \text { Harald Gropengiesser } \\ \text { Britt Lindahl } & \text { Harrie Eijkelhof } \\ \text { Camilla Schreiner } & \text { Harriet Axelsson } \\ \text { Carl Angell } & \text { Helge Strömdahl } \\ \text { Carolyn Boulter } & \text { Inga Wernersson } \\ \text { Christina Ottander } & \text { Irmeli Palmberg } \\ \text { Christina Kärrqvist } & \text { Jan-Erik Hagberg } \\ \text { Doris Jorde } & \text { Jari Lavonen }\end{array}$

Jens Dolin

John Leach

Jouni Viiri

Karl-Göran Karlsson

Kerst Boersma

Kirsti Lonka

Lise Kvittingen

Marcus Grace

Marcus Hammann

Margareta Ekborg

Mariana Hagberg

Marianne Ødegaard

Marit Kjærnsli

Merethe Frøyland

Ola Magntorn

Olle Eskilsson
Per Morten Kind

Per-Olof Wickman

Phil Scott

Piet Lijnse

Pål Kirkeby Hansen

Reinders Duit

Rie Troelsen

Rolf V. Olsen

Sonja Mork

Stein Dankert Kol-

stø

Svein Sjøberg

Sverker Lindblad

Sverre Pettersen

Ulla Runesson

Ute Harms

Veijo Meisalo

I detta nummer av NorDiNa erbjuder vi sex artiklar. Lena Hansson och Britt Lindahl frågar om dagens ungdom delar Fuglesangs vision om att människor i framtiden skulle bosätta sig på t.ex. planeten Mars och om denna vision utgör något som kan antas öka intresset för naturvetenskap och teknik. I nästa artikel diskuterar Barbro Gustafsson det dubbla uppdraget som lärare har genom att både ha ett kunskapsuppdrag och ett demokratiuppdrag. I den tredje artikeln undersöker Maria Åström och Karl-Göran Karlsson om PISA resultat vad gäller elevers kunskaper inom scientific literacy påverkas av hur undervisningen organiseras, i integrerad naturvetenskap, skolämnena var för sig eller både och. Robert Evans och Carl Winsløw resonerar i sin teoretiska artikel om fundamental situations och hur dessa kan användas som modeller för design av situationer för lärande av specifikt innehåll. I den femte artikeln studerar Astrid Berg, Ragnhild Löfgren och Inger Eriksson kemiundervisning i årskurs 4 och diskuterar det potentiella och det konstituerade kemiinnehållet. I den sjätte och sista artikeln diskuterar Åke Ingerman, Shirley Booth och Cedric Linder hur studenter som läser fysik på universitetsnivå förstår sin situation och hur lärare kan hjälpa studenterna att få en helhetssyn på sitt lärande i relation till ett fysikinnehåll. Vi fortsätter med ytterligare ett kapitel från boken Naturfagdidaktikk - perspektiver, forskning, utvikling skrivet av Andreas Quale. Här tar han sig an begreppet konstruktivism och ger oss en översikt över de olika betydelser detta begrepp har fått inom naturvetenskapsdidaktik. Detta NorDiNa nummer avslutas med sju avhandlingspresentationer.

Om vi till slut skulle önska oss något nu i stundande juletider så är det att ni skriver fler manuskript och skickar in till oss i NorDiNa. Under år 2007 har vi tillsammans skrivit färre artiklar än de båda föregående åren, 2005 och 2006. Kan en av anledningarna vara ESERA konferensen tro? Den krävde både bidrag och reviewarbete från många av oss. Om detta är fallet ser vi fram emot ett mycket produktivt år 2008 för NorDiNa.

Gott Nytt År med både skrivning för och läsning av NorDiNa!

Med hälsning från redaktörerna,

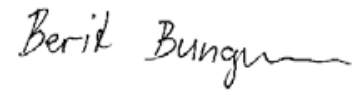

Berit Bungum

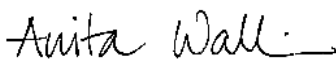

Anita Wallin

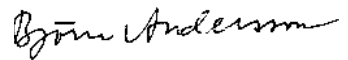

Björn Andersson 